\title{
Modernizm ve Gelenek Arasında Bir Ütopya: Maske ve Ruh
}

\author{
Fatma Şimşek \\ Akdeniz üniversitesi Sosyal Bilimler Enstitüsü \\ Türk Dili ve Edebiyatı ABD Yüksek Lisans Öğrencisi \\ fatmasimsek-07@hotmail.com
}

Öz

Modernizm, 18. yüzyılda Avrupa'da başlayan zamanla bütün insanlığı düşünce, sanat ve yaşam biçimi olarak etkileyen aydınlanmadır. En belirgin özelliği din ile geleneği reddetmesi; medeniyetin ilerlemesi için bilimi, teknolojiyi ve insanı esas almasıdır. Modernizmin öncelikli işi tarihi ve köklü bir birikimi olan geleneğe ve eskiye karşı çıkmak olmuştur. Bu yaşam biçimi din-dışılığı benimsemiş ve inançları eleştiriye açmıştır. Geleneksel ve dini değerler bu düşünce tarzına bir süre karşı koyduysa da değişime çok da direnememiştir. Modernizmin başta bütün kutsal değerleri ve geleneği yok edip kendine özgü nitelikler getireceği düşünülse de başarılı olamamıştır. Ve tahrip etmeye çalıştığı kutsal değerler evrilip dönüşerek modern hayata uyum sağlamayı başarmıştır. Bu yaşam biçiminin başarılı olamaması Batılı toplumlar gibi Doğu toplumlarını ve aydınlarını da olumsuz yönde etkilemiştir. Ve bu durum sosyal hayat kadar sanata da yansımış, aydınların içinde bulunduğu çelişkili, buhranlı durumu görmek mümkün olmuştur. II. Meşrutiyet Dönemi sanatçılarından Halide Edip Adıvar'ın yazmış olduğu Maske ve Ruh adlı tiyatrosu modernizm ile gelenek arasında kalan toplumun çelişkileri etrafında şekillenmektedir. $\mathrm{Bu}$ bağlamda çalışmada karakterlerin bakış açısı doğrultusunda modernizm ile gelenek arasında kalan dönemin aydını ve toplum incelenmeye gayret edilecektir.

Anahtar Kelimeler: Modernizm, gelenek, Halide Edip Adıvar, Maske ve Ruh. 


\title{
An Utopia between Modernism and Tradition: Mask and Spirit
}

\begin{abstract}
Modernism is the enlightenment that influences all mankind as thought, art and life style which started at the beginning of the $18^{\text {th }}$ century in Europe. The most prominent feature of modernism is to refuse tradition and religion. Modernism is based on science, technology and human. The first work of modernism was to oppose the historically rooted tradition. This life style has adapted non religion and opened the way for criticizing beliefs. Although traditional and religious values have opposed to this opinion style for a while, these values could not resist. At first, it was considered that modernism would destroy all sacred values and tradition would bring its own qualities but it did not succeed. At the same time, the sacred values that were expected to be destroyed have evolved and transformed to modern harmony. The failure of this lifestyle has affected not only the eastern societies and intellectuals but also the western societies in a negative way. This situation was reflected in art as well as social life. It has been possible to see the contradictory situation of the intellectuals. The play named "Mask and Spirit", written by Halide Edip Adıvar who is one of the constitution period artists, is shaped around the contradictions of society between modernism and tradition. In that context, it will be attemped to examine the intellectuals and society of period between modernism and tradition in terms of the viewpoint of the characters.
\end{abstract}

Keywords: Modernism, tradition, Halide Edip Adıvar, Mask and Spirit. 


\section{GíRiş}

Avrupa, Ortaçă̆'da bilim ve medeniyet olarak en karanlık dönemini yaşarken Rönesans ve Reform gibi gelişmeler, coğrafi keşifler, teknoloji ve bilim alanındaki ilerlemeler ile düşünürlerin çoğulcu bakışı sayesinde aydınlığı ve modernliği temsil etmeye başlamıştır.

Aydınlanma hareketine dayanan "modern" kelimesi, Latince "modernus"tan gelmektedir. Modernus ise Latince "modo"dan türetilmiştir ve "hemen şimdi" demektir. Dolayısıyla şimdiki zaman yüceltilmiştir. "Modernus" ilk olarak Hıristiyanlığı, köklü Roma ve Pagan kültüründen ayırmak için V. yüzyılda kullanılmıştır. Bu yüzden "modernus" köken olarak, eskiye ve antik kültüre karşı ortaya atılmış bir şimdiki zaman kavramıdır (Kızılçelik 1994:87).

"Modern" kelimesi terim olarak çok eski bir tarihçeye sahiptir. "modernite" projesi olarak 18. yüzyılda aydınlanma düşünürlerinin bütün alanlarda kitlesel olarak ortaya koydukları olağanüstü bir düşünsel çabadır. Aydınların amacı insanlığın özgürleşmesi ve günlük yaşamın zenginleşmesi için özgür ve yaratıcı bir biçimde çalışan çok sayıda bireyin katkıda bulunduğu bir bilgi birikimini kullanmaktır (Harvey 1997: 24).

Modernizm ile beraber kentsel ve sosyal dönüşümün hızlanması için pek çok düşünce ve tavır sergilenmiştir. Bu tutum ve davranışlara uygun olmayanlar ise çağ-dışı olarak nitelendirilmiştir. Buradan hareketle "modernlik" son üç yüzyıldır Avrupa'da başlayarak bütün dünyayı etkisi altına alan ve sanayileşmenin hızlandırılmasındaki en önemli dönüşümdür denilebilir. "Modernizm" ise yaşanan büyük dönüşümün neticesinde ortaya çıkan durumu kutsayan ve bu dönüşümü belirli bir zümre ya da zihniyete mal ederek bu duruma uygunluğu iddia eden bir söylem biçimidir (Aktay 2008: 10).

Modernizmin ortaya çıkışındaki temel nedene inildiğinde Rönesans (14-17. yy) hareketini gösterebiliriz. Fransızcada "yeniden doğuş" anlamına gelen bu kavram Batı uygarlığı için önemli bir ideolojidir. Çünkü Ortaçağ'dan itibaren kilise merkezli yaşayan Batı toplumları için Tanrı algısının yerini, insan odaklı bir düşünce sistemi almıştır. Rönesans, reform ve sanayi devrimiyle birlikte bilimsel bilgi "Tanrı"nın yerini almaya başlamıştır. Nitekim Batı; felsefe, fizik ve keşfedilmesi beklenen her alandaki açıklamayı Tanrı'nın varlığı yerine akılla açıklamaya başlamıştır (Koçakoğlu 2012: 17).

Düşünürler artık kilisenin hegomanyasından kurtularak "din" ile yollarını ayırırlar. Aydınlar, buradan hareketle devlet yapısındaki dinin belirleyici kurumlarını kovar ve kiliseyi kendi alanı içine hapseder. Çünkü filozoflara göre din insanlığı mutsuz eden bir inanç sistemidir. Buradan hareketle dinin dışarıda bırakıldığı ve rasyonel bir topluma dönüşmeye çalışıldığı görülmektedir. Ancak asıl bilimsel devrimi Newton başlatmış ve evrensel yerçekimi kanununu keşfederek iki dünya görüşü arasındaki kopuşu netleştirmiştir. Artık Tanrı tarafından idare edilen ve sadece Tanrı'nın ihtişamını anlatan bir doğa yerine, insanın aklı ve bilimsel bilgiyle yönettiği bir sistem netleşmiştir.

Ardı sıra yaşanan bu gelişmelerle birlikte sanayi devrimi ivme kazanmış ve Avrupa'daki feodal yapı dönüşmeye başlamıştır. 1789'da Fransa'da yaşanan siyasi devrimle beraber din savaşları bitmiş ve Avrupa'nın feodal düzeni yerini ulus-devlet anlayışına bırakmıştır. Bununla birlikte Batı'da başlayan ham madde ihtiyacıyla hızla ilerleyen sömürgecilik anlayışı belirli grupların ekonomik ve siyasi varlığını güçlendirirken sömürü altındaki toplumların hayatını mahvetmiştir. Avrupalı devletler sömürge yarışı, ulus-devlet anlayışı gibi aydınlanmanın getirdiği pek çok çıkmaz yüzünden savaşın eşiğine gelmiştir.

İnsanlık tarihinin en önemli dönüşümlerinden biri sayılan modernizm, filozofların ve toplumların beklentisini karşılamaya yeterli olmamıştır. Nitekim bilimsel bilginin, 
ekonominin, sömürünün, mühendisliğin, fiziğin önderliğinde mutluluğu arayan aydınlar modernleşme çabasıyla iki büyük dünya savaşının yaşanmasına yol açmışlardır. Batı medeniyeti modernizm döneminde insanlığa büyük acılar ve kayıplar yaşatmıştır. Toplumlar kitlesel olarak bir kaosa sürüklenmiş ve çıkmazda kalarak bunalıma girmiştir. Aydınlanma süreciyle birlikte bilimi tek kurtuluş olarak gören insanlığın bilime olan güveni sarsılmıştır.

Sonuç olarak antik pagan kültürüyle dönüştürülen Hiristiyanlık -kilise- otoritesinden ve geleneklerinden koparak, insanı merkeze alan bir dönüşümün içine giren Batı, teknoloji sayesinde mücadeleye başlamıştır. Avrupa'daki bu gelişmeler sömürü yarışını beraberinde getirmiştir. Fakat Batı kendi kültürünü yaymak istediği sömürge devletlerinden direniş gördügünde onları ortadan kaldırmaya çalışmıştır. Ve bu süreçte emperyalist güçler insanlığı kaosa sürükleyen büyük acılar yaşatmıştır.

Türkçede "gelenek" kavramı "Bir toplumda, bir toplulukta eskiden kalmış olmaları dolayısıyla saygın tutulup kuşaktan kuşağa iletilen, yaptırım gücü olan kültürel kalıntılar, alışkanlıklar, bilgi, töre ve davranışlar, anane, tradisyon" olarak geçmektedir (AkalınToparlı vd. 2011: 920). Gelenek kavramı anlam olarak kullanıldığı yere göre çeşitlilik göstermektedir. Edebiyat, felsefe, sosyoloji ve din alanlarında terimsel olarak kullanılmaktadır. Geleneğin İngilizce karşılığı olan tradition Latince bir sözcük olan tradere sözcüğünden türemiştir. Tradition sözcüğü; başkasına aktarmak, teslim etmek, birine vermek anlamlarına gelmektedir (Güneş 2014: 20).

Gelenek bir toplumun köklerine ait izler taşımakta ve hafızasını oluşturmaktadır. Geçmişten gelen sanat, kültür, edebiyat ve inanç gibi pek çok birikimle toplumların beraberliklerini kuvvetlendirdiğini söyleyebiliriz. Yasalaştırılmış ya da resmileştirilmiş bir durumu olmayan geleneğin aklın ve bilimin ötesinde yaptırım gücünün olduğu bilinmektedir. Gelenek kavramı anlamından da hareketle etkili bir güce sahiptir ve bu durum modernizm ile geleneği karşıtlı̆̆a getirir. Çünkü modernizm akıl ve bilimle açıklayamayacağı hiçbir şeyi kabul etmemektedir. Toplum asırlardır gelen kültürünü modernizmin etkisiyle terk etmeye çalışsa da ilk aşamada çıkmazda kalabilmektedir.

Modernizm, Tanrı'nın ve geleneğin yerine aklın ve bilimin dayatıldığı ancak bu şekilde kurulan bir dünya düzeninin refahı sağlayacağını ileri süren düşünce biçimidir. Kültüre, inanca ve geleneğe ait olan akıl ve bilimle açıklanamayan her şeyi yıkmaya çalışır. İnanç ve gelenek toplumun yaşamını ve hareketlerini kendi isteği dışında şekillendirdiği için bireyin aklını ve bilimi bir kenara bırakmaktadır. Modernizm aklın ve bilimin hâkim olmadığı her şeyi reddettiğinden inancı ve geleneği ortadan kaldırmaya çalışır. Bunu gerçekleştirmek içinde sanattan, felsefeden ve edebiyattan faydalanmaya çalışılır.

Yaşanan tarihi, siyasi ve felsefi gelişmeler karşısında edebiyatın kayıtsız kalamadığı görülmektedir. Edebiyatta modernizm, dönemin karanlık yapısını yansıtan bir dönüşüm olarak karşımıza çıkmaktadır. Freud ve Jung'ın çalışmaları neticesinde yirminci yüzyılda sanat ve edebiyatında etkilendiği söylenmektedir. Modernist edebiyatta sanatçılar özellikle bilinçaltı ve insanın iç dünyasına eğilerek karakterlerin aktarımında yenilikler meydana getirmişlerdir. Nitekim Nietzsche'nin, Tanrı'nın madde karşısında öldüğünü söylemesiyle, Tanrı düşüncesi yıkılır. Ve bu dönüşümlerle bağlantılı olarak modernist edebiyatta zaman, mekân ve olay örgüsünde farklı teknikler uygulandığı görülür (Ecevit 2001: 28).

Edebiyatta modernizm yalnızca geleneğe karşı çıkmakla kalmaz,"birey"i merkeze alarak onun varoluşunu önceler. Bu yaklaşımla "birey", toplumdan ve onun ruhsal 
yapısından uzaklaşmaktadır. Modernist edebiyatta, "birey" merkeze alındığı için bilinç akışı ve iç monolog gibi modern teknikler kullanılmaktadır.

Modernist yazarların okuru bilinçlendirmek veya yol göstermek gibi bir amacının olmadığı söylenmektedir. Brecht'in ise tiyatro alanında "yabancılaştırma estetiği"ni kavramsallaştırdığı görülür. Buna göre amaç seyircinin tiyatro oyunuyla bütünleşmesi değil, gerçeğin izleyiciye dikte edilmeden aktarılması ve seyircinin oyuna olan mesafesini koruyarak gerçekliğin farkına kendisinin ulaşabilmesidir (Ecevit 2001: 37).

Modernistler kökleşmiş olan kültürü yıkmaya çalışsa da bu durum zaman alır. Aydınlar aklın ve geleneğin ikileminde kalırlar. Bu bakımdan gelenek ile modernizm arasında çelişkiler yaşayan aydının ve toplumun durumu edebiyat eserlerine de yansımıştır. Bu bağlamda II. Meşrutiyet dönemi düşünürlerinden biri olan Halide Edip'in Maske ve Ruh isimli tiyatrosunda gelenek ile modernizm çatışmasında kalan aydın kesim ve toplum incelenmeye gayret edilecektir.

\section{1.İronik Bir Ütopyaya Doğru: Maske ve Ruh}

Hikâye ve romanları ile tanınan Milli Mücadele döneminin önde gelen isimlerinden Halide Edip'in tiyatro türünü de kullanarak kaleme aldığı eserleri bulunmaktadır. Geleceğe ve toplumun dönüşümüne, ileride yaşanması muhtemel olan tartışmalara bu türü kullanarak yer vermiştir. Maske ve Ruh ismini verdiği tiyatrosunda toplumun tarihi, kültürel, siyasi ve dinsel sorunları maske ve ruh ilişkisiyle işlenir. Oyun bir prolog ve dört perdeden oluşmaktadır. Birinci perde dört, ikinci perde yedi, üçüncü perde sekiz ve dördüncü perde beş sahneden müteşekkildir. Oyunda modernizmi ve Batılı yaşam tarzını benimseyenler ilerici ve aydın olarak belirtilirken, inançlarını ve geleneğini sürdürmek isteyenler gerici ve yobaz olarak gösterilmektedir. Bir de eserde modernizm ile gelenek arasında çıkmazda kalan sürekli çelişki yaşayanlar bulunmaktadır. Yazar, böyle bir kaotik ortamda Nasrettin Hoca'nın mizahi üslubuyla esere yaklaşır ve geleceğe ait öngörüsüyle ideal bir dünya nasıl olmalı sorusunun cevabını arar. Hem işlediği konu hem de eserin başında belirttiği gibi Adıvar'ın geleceğe ait fikirlerinin bulanık olduğunu söyleyebiliriz:

"Yarının dünyasında huzur veya çatışma unsuru olabilecek bütün bu meseleleri on sene önce ciddi bir şekilde yazmadan evvel, Nasreddin Hoca gibi kavramak istedim. Isste bu anlayışla ve bilhassa geleceğe hâkim olabilecek değerlerin birbirine karşıt gibi görünmeleri bana yön tayin ettiremeyen bir fikri pusulasızlık verdiği için kahramanı Nasreddin Hoca olan fanteziyi yazdım." (Adıvar 1918: 38) ${ }^{1}$

Halide Edip Avrupa, Amerika ve Hindistan gibi dünyanın çeşitli kültürlerini yakından tanıyan bu toplumlarda gözlemlediği problemleri ve insanlığı derinden etkileyen savaş, kıtlık, modernizm ve ideoloji gibi konuları Nasrettin Hoca üslubuyla yazmıştır. Yazar ileride yaşanmasını mümkün gördüğü ideolojik fikir çatışmalarının içinde kararsız kaldığını ve kendine bir yön tayin edemediğini dile getirir. Ve bunun sonucu olarak Nasrettin Hoca'nın mizahıyla ütopik fantezi bir eser yazdığını belirtir.

Maske ve Ruh temsili çok zor olan hayal gücünün sinırlarını zorlayan fantastik bir oyundur. Bu sebeple de sahnelenmesi pek mümkün değildir. Fakat Maske ve Ruh 2016 yılında Nedim Saban ve bir grup tiyatrocu tarafından modern yöntemlerle okuma tiyatrosu şeklinde sahnelenmiştir.

${ }^{1}$ Eserle ilgili bundan sonra yapılacak olan alıntılarda sadece sayfa numarası kullanılacaktır. SEFAD, 2017 (38): 161-178 
Adıvar eserinde ileride yaşanması mümkün olan toplumsal meseleleri din, ölüm, siyaset ve modernleşme gibi temalar etrafında ruhun önemini vurgulayarak bahsetmiştir. 21. yüzyılda insanlığın ruha olan inancını kaybederek birbirine benzeyen sahte maskeler altında gizleneceği öngörüsünde bulunmuştur. Bu durumu eleştiren ve kesin bir yargıya varamayan Adıvar, konu hakkındaki görüşlerini başkahraman Nasrettin Hoca ve Shakespeare, Timurlenk, İbn-i Haldun gibi çeşitli karakterler aracılığıyla dile getirmiştir.

Yazar farklı medeniyetler tanıdığı için ele aldığı konuları bu toplumların kültürlerinden yola çıkarak işlemiştir. Hindu kültürüne ait olan reenkarnasyon (tenasüh) ve her varlığın insan olana kadar ölüp çeşitli suretlerde pek çok defa dünyaya gelip gitmesi gibi İslam'a ve geleneğe ters düşen inançlara yer verilmiştir. Eserde ölüm, ahiret hayatı gibi durumlar İslam'dan uzak bilim-kurgu ve fantastik çizgilerde anlatılmıştır.

Eserine Nasrettin Hoca'nın mizahi yapısıyla bakan Adıvar, daha çok soyut teknikler ve monolog kullanmıştır. Eserin karakterlerinde olduğu gibi zaman ve mekânında da çeşitlilik görülür.

Eser konusunu Nasrettin Hoca'nın ölümü ile ahiret yolculuğu sırasında yaşadıkları, dünya yaşamı hakkındaki görüşleri ve makineleşerek maddiyata önem veren, ruhunu kaybeden tümüyle maskeleşmiş toplum düzeninden alır. Nasrettin Hoca ahiret hayatındayken en yakın arkadaşı Şekispir ile maskeleşmiş insanlara ruhun önemini anlatmak ve toplumu içinde bulunduğu kaostan kurtarmak için başka bir insan suretinde dünyaya görevli olarak gönderilir.

Eserde ironik durumlar fazlaca göze çarpmaktadır. Aslında Adıvar'ın netleşemeyen düşüncesi eserdeki zıtlıklarda da görülebilir. Nazım Hikmet'in "Makineleşmek" şiiri ile Yunus Emre'nin Vahdet-i Vücut anlayışılla yazılmış şiirleri veya Şekispir'in elinde kadehiyle konuşması yahut Bilal-i Habeşi'nin ezan okuması gibi sahneler eserdeki ironik duruma örnek gösterilebilir.

Nasrettin Hoca ve Shakespeare dünyadaki görevleri bitince ahiret hayatına geri dönerler. Orada olup biten her şeyi İbn-i Haldun'a anlatırlar. Artık toplumların kurtarılamayacak kadar madde âleminde olduklarını, makineleşmek için ellerinden gelen her şeyi yapan insanların ruhlarını kaybetmiş etten birer maske olduğunu anlatırlar.

Nasrettin Hoca ile Shakespeare insanlıktan umudunu kesmiş bir şekilde bir daha asla dünyaya gitmek istemediklerini söylerler. İbn-i Haldun ise onların dünyadan ahirete gelesiye kadar bir yüzyıl geçtiğini sonunda insanların ruha daha çok önem verdiklerini ve ahiretteki herkesin dünyaya tekrar gitmeyi çok istediğini dile getirir. Her ne olursa olsun dünyaya bir daha asla dönmek istemediğini söyleyen Nasrettin Hoca'ya, mizahının her devirde devam edeceğini der ve oyun biter.

Adıvar, geleceğe dair öngörüsüyle yazdığı Maske ve Ruh isimli tiyatrosunda genel olarak Cumhuriyet dönemi aydınlarının, modernizm ve gelenek arasındaki ya da madde ile mana arasındaki çatışma ve kaotik durumunu anlatmaktadır.

Adıvar eserde gelecekte Doğu toplumlarının yaşayabileceği muhtemel bir soruna yer vermiştir. Eserde insanların artık modern hayatın gereklerine uyarak robotlaştığı, makineleşerek birer maske taktığı yansıtılır. Oyunun başkişilerinden Nâsır (Nasrettin Hoca) insanlara unuttukları manevi kavramları, ruhun ve eskinin önemini hatırlatmak ister. Cennet, cehennem ve dünya arasında geçen fantastik bir oyundur.

Pek çok dünya kültürünü yakından tanıyan yazar, başta Türkiye olmak üzere diğer toplumların ileride modernizm ve gelenek sorunsalı yaşayacağını öngörmüştür. Fantastik 
bir kurguyla kaleme aldığı eserini gelenek ve modernizm çatışmaları, konu yönüyle çatışmalar ve metinlerarasılık bağlamında incelemeye çalışılacaktır.

\section{Gelenek ve Modernizm Çatışmaları}

Gelenek toplumun uzun bir süre içinde birikimiyle kendine has bir yaşam şekli oluşturmasıdır denilebilir. Nitekim sanat, edebiyat ve din gibi daha pek çok konuda toplumun ortak paydada buluşmasını ve birlikteliğin güçlenmesini sağlamaktadır. Gelenek bunu sağlarken de kişinin iradesi ve isteği dışında dayatılarak uyulması gereken kurallar bütününü oluşturur.

Modernizm ise aklın ve bilimin laboratuvarından geçmeyen her şeye karşıdır. $\mathrm{Bu}$ yüzden geleneğe ve eskiye cephe almaktadır. Maske ve Ruh isimli eserde ise gelenek ve modernizmin çatışması kahramanlar, inanç ve ahiret çatışmaları gibi durumlar etrafında verilmektedir. Aşağıda bu başlıklar çerçevesinde gelenek ve modernizmin karşıtlığı incelenmeye gayret edilecektir.

\subsection{Figüratif Çatışmalar}

Yazarın içinde bulunduğu çıkmazı kahramanlar aracılığıyla vermeye çalıştı̆̆ını söyleyebiliriz. Bazı kahramanlar Doğu'nun geleneksel öğretisini temsil ederken, bazıları Batı'nın geleneksel öğretisini temsil etmekte ve modernist bir düzeni savunmaktadır. Ayrıca toplumda her iki düşünce arasında kendine yer bulamayan fikir bulanıklığı yaşayanları da yansitan kahramanlar vardır.

Nasrettin Hoca, Nâsır suretinde dünyaya tekrar gelmiştir. Nâsır Akşehir'e devletin verdiği bir görevle gelir orada pek çok insanla tanışır. Ve neredeyse tanıştığı herkes aynı maskeyi takmış maddi âlemi, makineleşen dünyayı sevmektedir. Böyle bir ortamda Selime ile tanışan Nâsır onunla aynı ruhu paylaştığını, hayata aynı pencereden baktığını fark eder. Selime'nin ailesi ve tüm çevresi ruhun, duygunun geçiciliğinden ve ruh diyen insanların gerici, eski kafalı olduğundan dem vurur. Eserde öne çıkan bazı karakterler; Remziye Bektay ve kızı Selime, Nâsır'ın annesi Sabire Cebe, Zehra öğretmen, Maria ve Olga'dır.

Remziye Bektay ile Selime Bektay anne-kız olmalarına rağmen sık sık karşı karşıya gelirler. Onların ilk karşıtlıklarını üçüncü perdenin üçüncü sahnesinde görmek mümkündür. Remziye Bektay modern yaşamı benimsemiş ve eskiyi reddetmiş bir annedir ayrıca kızının da aynı zihniyette olmasını ister. Bir sohbetleri esnasında; "REMZIYE: ...asıl modern devir yalnız eski işe yaramaz binaları değil, köhne ihtiyarları da ortadan kaldıracak kadar pratik fikirli olduğumuz vakit başlayacak." (s. 85) sözleriyle kızı Selime'yi uyardığı görülmektedir.

Nasrettin Hocayı ve onun türbesini eskimiş bir kültür olarak gören Remziye Hanım türbenin mimarisini modern tarzda yenilemiş ve sırf gerici bir görüntü olmasın diye etrafına oyun parkı yaptırmıştır. Remziye Bektay'a göre eskimiş her ne varsa köhne ve gerici kabul edilmelidir.

Eserde Selime Bektay için öğrenme büyük bir arzu haline gelmiştir. O Akşehir'in ileri gelen ailelerinden birinin kızıdır. Ayrıca modern tarzda yetiştirilmiş ve iyi bir eğitim alarak tıp doktoru olmuştur. Fakat bunlarla yetinmez sürekli olarak yeni bilgiler edinme, araştırma arzusundadır. Hatta sık sık bu bilgilerini erkeklerin yoğunlukta olduğu ortamlarda da dile getirerek onlarla entelektüel anlamda rekabete girmektedir. Bu sohbetler esnasında çoğu zaman annesi Remziye Hanım'la zit düştüğü durumlar olur. Selime eskiye, kültürel ve geleneksel değerlere kıymet veren bir genç kızdır. Fakat Nâsır'la yaptığı bir sohbetten anlaşıldığı üzere modernizm ile gelenek arasında bir çıkmazda olduğu görülmektedir. 
Selime eserde, geleneklerine bağlı olan bir babaannesi olduğunu ve eskiden ona çok benzediğini ama sırf modern olmadığı için dışlandığını ve hiç arkadaşının kalmadığını dile getirir. $\mathrm{Bu}$ durumu fark edince döneme ve çevresine ayak uydurmak için modern görünmeye çalıştığını anlatır.

Sabire Cebe, Nâsır'ın annesi ve Nasrettin Hoca'nın torunlarındandır. Eskiye, gelenek ve kültüre bağlı bir kadındır. Onun; "SABIRE: "Nasrettin hocayla hemşeriyiz demek istiyorum. Modern olduk diye insanları dükkân camekânına dizilmiş kuklaya çevirmek istiyorsunuz. Biz Akşehirliler dünya yıkılsa yine kendimize de dünyaya da gülmekten vazgeçmeyiz." (s. 96) cümleleri bu durumun en net örneklerindendir. Sabire Hanım eserde, geleneksel öğretiye sahip bir zihniyette görülmektedir. O, eskiye ve ruha önem veren, sahip çıkan bir karakterdir.

Zehra öğretmen Akşehir'de bir ilkokul öğretmenidir. Öğrencilerini modern anlamda yetiştirmeye çalışır. Her gün çocukları Akşehir parkında "makineleşmek istiyorum" şarkısını söyletir. O da Remziye Hanım gibi mekaniğe ve moderne önem veren biridir. Fakat Kalopatya'ya gittiklerinde bir akşam Şeyk ile Selime dışarı eğlenmeye gitmek isterler. Zehra'da nişanlı bir kızın bekâr bir erkekle eğlenmeye gitmesinin kültürümüze uygun olmadığını söyler. Selime ise bunun eski kafalı insanlara ait bir düşünce olduğunu dile getirir (s.120). Bu bağlamda iki karakterin de modernizm ve gelenek arasında gel-gitler yaşadığı söylenebilir.

Eserin sonuna doğru ütopik bir ülke olan Kalopatya'ya giden temsil ekibi orada Maria ve Olga adında iki kadınla tanışır. Bunlar Hıristiyan'dır ve modern anlamda yetişmişlerdir. Maria, Nasır'a ilgi duymaktadır. Bu yüzden Maria ve Olga'nın aralarında din üzerine geçen şu konuşma oldukça dikkat çekicidir:

“MARİA: Şimdiki zamanda artık din taassubu olur mu?

OLGA: Bu taassup değil. Hıristiyanlığın uygarlığımızın pınarı olduğu kanısındayız! Önce ne de olsa Müslümanlar vaktiyle kadınların kaparlardı. Sonra, bir türlü Hıristiyanlığı kabul etmeyen bir millet. Illk batılılaştıkları zaman herkes Hıristiyan olurlar diye umuda düştü. Boşa çıktı." (s.

Bu alıntı Hıristiyan-Avrupalının kendi dinine ve İslam'a bakışını göstermesi sebebiyle önemlidir. Diyalogdan yola çıkılarak Batı'nın medeniyetin tek kaynağı olarak kendini gördügünü ve modern anlamda geçerli olabilecek tek inancın Hıristiyanlık olduğuna inandığını söyleyebiliriz. Bununla beraber İslamiyet'te kadının eve kapatılması gibi bir durum iddia edilerek negatif bir tutum sergilenmektedir. Öyle ki bu iki karakter gerçek manada Batılılaşan her milletin Huristiyanlık'ı kabul etmeye başlayacağı algısını vermektedirler.

Modernizmle beraber aydınlar, toplumları huzursuzlaştıran tek neden olarak gördükleri dinden ve geleneksel yapıdan uzaklaşmaya çalışmışlardır. Bu tavrı sergilemeyenlere de çağdışı olarak bakılmıştır. İki karakterin diyalogunda da anlaşıldığı gibi modern olmaya çalışan ama bir şekilde geleneğin ve dinin etkisinden ayrılamayan bireyler görülmektedir.

Buradan hareketle yazarın oluşturduğu kadın karakterlerin farklı görüşlere sahip olduğunu söyleyebiliriz. Modernizmin başarısız olmasıyla aydınların çıkmaza ve çelişkili durumlara düştüğün görülür. Adıvar'ın eserindeki kadın karakterlerin çelişkili yapısı aslında yazarın içinde bulunduğu çıkmazı göstermektedir. 
Eserde gelenek ve modernizm arasında sıkışan erkek karakterler de vardır. Başbakan Timur Bey, Ahmet Cebe ve Mahir Torlan gibi karakterler ülkenin kurtuluşunun ruhta değil mekanikte yani teknoloji ve modernizmde olduğunu savunmaktadırlar.

Ahmet Cebe, Nâsır'ın babasıdır ve siyasi kimliğe sahip olup iktidara yakınlığıyla bilinen modern bir adamdır. Karısını ve oğlunu sürekli geri kafalı olmakla yargılamaktadır. Onun bu tavrını aşağıdaki örnekte görmek mümkündür.

Başbakan Timur, Ahmet Cebe'nin evine davetlidir ve Akşehir'in ileri gelen bütün modern aileleri bu davete gelecektir. Ahmet Cebe ile karısı Sabire arasında salona canlı çiçeğin mi yoksa yapma çiçeğin mi daha modern olduğu hususunda bir tartışma geçmektedir. Canlı çiçeği daha güzel bulan karısı Sabire Hanım'a şöyle söyler:

"Ahmet Cebe: ... zaten moda olan, yeni olan her şeye karşı sende bir kocakar direnmesi var. Bu salondan başka odaları görenler bizi iki yüzyıl önceki anlayışta sanırlar. Fakat çok şükür biz modern adamlarız; olmasaydık hiç başbakan evimize gelir miydi? ..." (s. 95)

Bu diyalogdan hareketle Doğu toplumlarının modernizmi tepeden inme bir şekilde sadece görünüşte ve madde olarak algıladıkları söylenebilir. Ahmet Cebe, eserde modern görünüşünün altında aslında eski kafalı biri olarak çizilmektedir. Onun modern görünmesinin tek nedeni siyasi ve maddi çıkarlarını sağlayabilmektir.

Mahir Torlan, Ahmet Cebe'nin yeğeni (Nâsır'ın kuzeni) olarak eserde görülmektedir. Yenilik taraftarı olan, tamamen modern ve profan (din-dışılık) anlayışa sahip bir karakter olarak karşımıza çıkar. Onun bu yapısını eser boyunca net bir şekilde görmek mümkündür. Remziye Bektay ile yaptığı sohbette şu sözleri onun bu zihniyet yapısı gösterebilir:

"Mahir Torlan: Ne de olsa halk yaşlı adamları tutuyor. Çünkü halk içinden biraz gerici... Çünkü modern görünüşüne rağmen amcam da gerici... Illerlemeden yana görülmesi sirf işini uydurup para kazanmak. Yarın imamlar bu memlekette hâkim olsa şapkayı atar sarık sarar... Yeni devrin yaşaması için bizim gibi ilerlemeye inanmış gençler iktidar mevkiine gelmeli." (s. 87)

Mahir Torlan, toplumun sadece belirli kesiminin modern, çoğunluğunun ise çağdış1 ve ilerleme karşıtı olduğunu vurgulamıştır. Ayrıca imamların ülke üzerindeki söz hakkını gerici bir hareket olarak belirtirken, şapkayı modern yaşamın iz düşümü, sarığı ise ilerleme karşıtı şeklinde göstermiştir. Buradan hareketle uluslaşma süreci Türkiye'sinin en yakın şahitlerinden biri olan Halide Edip'in modern ve geleneksel simgelere bakışına dair bir kanaat edinilebilir.

Bay Timur ise kuvvetli, modern ve Batılı bir zihniyete sahip iktidarın başbakanıdır. Bay Timur gençleri hayatı bilim kurallarına göre uygulayan Kalopatya'ya göndermek ister. Amacı gençlerin oradan edineceği bilgiyle modern bir yaşam biçimi ortaya çıarmaktır. Eserde "ruha" önem veren bir karakter olan Şeyk ile aralarında şöyle bir konuşma geçer:

"Bay Timur: Kılıçla, yumrukla dünyaya hükmetmeye modernlik ismi verilemez. Onlar ölünce eserleri de onlarla beraber ölür. Hâlbuki bizim kurduğumuz dünya o kadar kişisel ve keyfi etkilerden uzak güçlü bir devlet makinesi olacaktır ki, dünya durdukça biçimini ve gücünü kaybetmeyecektir...

Şeyk: Dünyanın eskiden beri hülyası bu... fakat siz de dünyadan göçtükten sonra geleceğin büyükleri, dahileri sizin makinenizi eskimiş bulur, zamanına uymaz bulur, yeni bir dünya 
kurmaya kalkar. İnsanda "ruh" denilen şey baki kaldıkça mutlak dünya biçimden biçime girecek, mutlak insanlar birbirinden değişik ve başka başka şeyler isteyeceklerdir...

Marifet insanları öldürüp onları devlet makinesinin arkasından ipini çekip oynattığı birer kukla saymamaktır.

Bay Timur: Ruh diye diye ruhu tepeliyorsunuz. İki bin yıldır dünya başkalık içinde ahenk aradı, bulamadı. Biz dünyaya bir örneklik içinde sulh, mutluluk ve kararlılık vereceğiz. Ve gerekirse "ruh" denilen şeyi de, görevini de kaybeden bir organ haline getireceğiz..." (s. 102)

Eserde de görüldügü gibi aynı dönemde yaşayan iki karakter farklı ideolojiye sahiptirler. Bay Timur modern, mekanikleşmiş ve ruhunu kaybeden tek tip toplum yapısını savunurken Şeyk'in ruha ve değerlere önem verdiğini söyleyebiliriz. Bay Timur, eskinin yok edilmesiyle yeni ve daha iyi bir dünya düzeni kurulacağını belirtirken, Şeyk ise ruhun var olduğu müddetçe hep yenilik ve değişiklik isteyeceğini ve zamanla yeni denilen her şeyin eskiyeceğini vurgular.

Eserde 21. yy'da yaşayan ve Nasrettin Hoca'nın ruhunun içine girdiği gelenek taraftarı olan karakter Nâsır'dır. Türk-İ̀slam kültürü ile geleneğine sahip çıkan, köktenci ve akıllı bir gençtir. Modern toplumun maskeleşmiş tavırlarına karşı çıkarak ruhun önemini vurgular. Fakat Nasreddin Hoca'nın onun içinden çıkıp arada sırada ahirete gidip geldiği anlarda modenizmi destekleyici cümleleri görülmektedir. Onun; "Hakkınız var efendim, ruh lakırdısı, geçmiş lakırdısı hiç de tekin değil... kaç bin yıldır dünyanın çektiği acı hep onların yüzünden... bir geçmişi unutabilsek hepimiz rahat edeceğiz." (s. 103) sözleri bu durumun en net örneklerindendir.

Eserde kimi zaman modernizmin kimi zaman geleneğin savunulduğu görülmektedir. Bu bağlamda eserdeki karakterlere bakıldığında hem dönemin aydınlarından olan Adıvar'ın hem de toplumun modernizm ile gelenek sorunsalı arasında kaldığı söylenebilir. Öyle ki karakterlerinin birbiri arasındaki görüş farklılıklarından ziyade kendi iç çekişmeleri görülmektedir.

\subsection{Tematik Çatışmalar}

Modernizm düşünürleri, Ortaçağ kilisesinin baskıcı tutumunu, din adamlarının kendi çıkarları doğrultusunda kutsal metinleri kullanmasını, halkın yoksulluğunu ve uzun süren savaşların temel sebebini inançlara ve geleneğe bağlamaktadırlar. Onlara göre insanlığın huzursuz olmasının en büyük etkeni dindir. Bu yüzden modernistler dini referans alan her şeye karşıdırlar. İnançları yıkmaya veya tahrip etmeye çalışırlar.

Bu bağlamda aşağıda Maske ve Ruh isimli eserde geleneği ve modernizmi temsil eden bireylerin inanç ve ahiret çatışmaları incelenmeye gayret edilecektir.

\subsection{1. İnanç Çatışmaları}

Adıvar eserinde çeşitli inanışlardan yola çıkarak ölüm, dirilme ve ahiret inancı gibi konulara yer vermiştir. Yazar, bu konuları ele alırken Doğu ve Batı medeniyeti başta olmak üzere pek çok medeniyetin kültürünü sentezleyerek yazmıştır.

Yazar, eserin giriş kısmında Nasrettin Hoca'nın ölümünü anlatarak esere başlamaktadır. Ve devamında Sultan Bayezid ile Timurlenk'in torununun ölümünün aynı gün olduğuna değinerek bu dünyada genç, yaşlı, köle yahut padişah olsun herkesin bir gün öleceğini yazmıştır.

Nasrettin Hoca öldükten sonra eşeği olmadan cennetin bile tadının olmayacağını düşünür. Hoca eşeğini aramak ve insanlığın ahvalini öğrenip geri döndüğünde 
ahirettekilere bildirmek için dünyaya iner. Bu esnada pek çok hayvan ruhunun bir arada olduğunu görür. Eşeğinin yerini öğrenmek için yanlarına gider. Bu olay birinci perdenin üçüncü sahnesinde gerçekleşmektedir. Burada Nasrettin Hoca bir tilkiden bilgi alır. Tilkinin dediğine göre, dünyadayken insanlar tarafından eza ve cefaya uğrayan hayvanlar, öldükten sonra dünyaya geri dönmek istemektedirler. Çünkü dünyaya tekrar geldiklerinde kendilerine zulmeden insanlardan öç almaya çalışırlar. Hoca Timurlenk'in vezirlerinden birinin eskiden kurnaz bir tilki olduğunu hatta eşeği Bozoğlan'ın da sarayda Timurlenk'e yakın bir şairin arkasına gizlendiğini öğrenir. Adıvar eserinde, her insanın içinde bir hayvan olduğunu hatta Timurlenk' in içinde bir kaplan olduğunu belirtir.

İnsanların ve hayvanların öldükten sonra farklı bir bedende dünyaya tekrar gelmelerinin Türk-İslam kültürüne uygun olmadığı bilinmektedir. Geleneksel Türk-İslam kültürüne göre öldükten sonra dirilme ancak kıyamet gününde gerçekleşmektedir. Tüm varlıkların dünyada yaptıklarından dolayı hesaba çekilerek bunun neticesinde cennete ya da cehenneme gönderileceği bilinmektedir. Fakat eserde bir Hindu kültürü olan reenkarnasyona (tenasüh) ya da hayvanların insan olana kadar dünyaya gelip gitmelerine inanılmaktadır. Yazarın, 1935'te Hindistan'a yaptığı gezi esnasında Hindu kültürüne ve inançlarına yakından tanık olması ilaveten Maske ve Ruh eserinde de bu kültüre ait izlerin bulunmasına binaen onun Hindu kültüründen etkilendiğini söyleyebiliriz. Buradan hareketle Adıvar'ın, farklı medeniyetlere ait çeşitli inanışları ve karşıt olguları bir araya getirdiğine dair kanaat edinilebilir.

Rönesans ile kilisenin (dinin) otoritesinden uzaklaşan Batı toplumları Aydınlanma Dönemiyle bilim ve teknolojide ilerlemiş, sömürge devletleri kurmuş ve ulus bilincine ulaşmışır. Fransız Devrimi'yle beraber hız kazanan ulus-devlet anlayışı ve sömürge devletlerinin başkaldırmaları sebebiyle uzun süren savaşlar yaşanmıştır. Bunun sonucunda aydın kesim ile halk bilimin-teknolojinin huzuru ve güven ortamını getiremediğini düşünmektedir. Aşağıda geçen diyalog bu durumun en net örneğidir:

"TEMSILCI: Fena şeyler var. Rahat ve huzur yok. Insanlar Arapsaçı halinde. Korkarım bu kargaşa, bu geçimsizlik dünyadan buraya da sıçrayacak!"

HOCA: "Bu nasıl olur? Burası cennet değil mi?"

TEMSILCI: "Sen buranın acemisisin evlat. Sana anlatayım: eski günlerde dünyada insanı birbirinden ayıran bir din vardı. Fakat buraya gelince o ayrılık kalkardı. Şimdi orada insanı birbirinden ayıran bin bir başkalık var, en büyüğ̈̈ renk ve ırk ayrımı. Sarı adam, siyah adam, Arî' Turani daha bilmem ne isimli ırklar herkesi birbirinden ayırıor..." (s. 60-61)

Diyalogdan da anlaşılacağı üzere eskiden dünyadaki dini inançların insanları çatıştırdığı, huzursuz ettiği ve ayrışmaya neden olduğu lakin artık inançsal karşıtlıklara renk ve ırk ayrımı gibi etkenlerinde eklendiği söylenmektedir. Buradan hareketle modernizm düşünürleri bireyi ayrıştıran, huzursuz eden ve karşıt bir durumda bırakan tek etkenin inançsal çatışmalar olduğunu düşünürken, Fransız İhtilali ile hızla yayılan ulus-devlet bilincine bağlı olarak toplumlar arasında pek çok ayrışma gerçekleşmiştir. Bu bağlamda inançsal çatışmaların toplumları ayrıştırdığını düşünen birey bu seferde milliyetçilik akımının getirdiği ayrışmayla karşılaşmaktadır.

\subsubsection{Ahiret Alg1sı}

Halide Edip, Nasrettin Hoca aracılığıyla ahiret hayatına da değinmiştir. Eserde verilene göre dünya-orta cennet- cennet ve cehennem gibi bölümler vardır. Hoca burada pek 
çok nesepten, dinden ve kültürden insanla tanışır. İkinci perdenin birinci sahnesinde, Hoca firuze kanatlı bir melekle karşılaşır ve aralarında ilginç bir konuşma geçer. Bu diyaloga göre Melek, dünyada iken ak yüzlülerden hep zulüm gördüğü ve oraya bir daha asla dönmek istemediği anlaşılmaktadır. Melek, siyah yüzlülerin bir süre dinlenip cennetin havasına alıştıktan sonra, ışıklı tarafa ak yüzlü melekler ülkesine gittiklerini, bazılarının ise burada kaldığından bahseder. Devamı şöyledir:

"HOCA: Siz Müslüman değil misiniz? Müslüman için dünyada, ahrette ak yüzlü, siyah yüzlü olur mu? Buraya da Müslümandan başkası giremez ya!

MELEK: Nasıl girmez! Cennete bin bir yol vardır. Herkes kendi yolundan gider. Biz Müslümanlık nedir bilmeyiz. Biz İsa ümmetiyiz.

HOCA: Ne de olsa ehl-i kitap sayılırsinız, fakat diyarını nice diyardır ki, Müslümanlık nedir bilmiyor?

MELEK: Amerika." (s. 58)

Eserdeki sahneden anlaşılacağı üzere okurun karşısına; dünyada insan olup öldükten sonra melek olan yahut onun vasfında görev yapan bir kadın karakter çıkar. Hâlbuki Türkİslam kültüründe ve geleneğinde insan ile melek iki ayrı varlıktır. Ayrıca İslam akaidine ters düşen bir durumda bu varlıkların cinsiyeti meselesidir. İslamda imanın şartlarından birinin meleklere iman olduğu bilinmektedir. Ayrıca bu varlıkların cinsiyetsiz olduğuna inanılmaktadır. Yani İslam kültüründe onların kadın ya da erkek olarak vasıflandırılmadığı görülmektedir.

Bir diğer durum ise cennete Müslümandan başkasının girip girmeyeceği hususudur. Nasrettin Hoca Müslümandan başkasının cennete giremeyeceği düşüncesini taşırken melek ile konuşup onların İsa ümmeti olduğunu ve Müslümanlığı bilmediğini öğrenir. Ne de olsa ehl-i kitap oldukları için cennete girmelerinde bir beis görmez. Oysaki Kur'an-ı Kerim'de bu durumun tersi ifadelerin yer aldığı bilinmektedir. Modernizm ile yaygınlaşan profan(dindışılık) anlayışın aynı zamanda kutsal metinleri ve kültürleri tahrip ettiği görülmektedir. Burada Adıvar 'ın, modernizm ve İslam arasında çıkmazda kaldığını söyleyebiliriz. Bu konuda Kur'an-1 Kerim'de Hıristiyan ve Yahudi halk için şöyle ayetler geçmektedir:

"Iman edenler ile Yahudiler, Sabiiler ve Hristiyanlardan Allah'a ve ahiret gününe (gerçekten) inanı iyi amel işleyenler üzerine asla korku yoktur; onlar üzülecek de değillerdir." (Mâide 5/69) (Özek-Karaman vd. 2012: 113) ${ }^{2}$

Daha önceden birinin dini ne olursa olsun ve ne kadar günah işlemiş bulunursa bulunsun son peygamber Hz. Muhammed'e (s.a.v.) uyup doğruca iman ediyor ve imanının gereğini yapıyorsa ahirette korkacağı bir şey olmadığı bilinmektedir. Fakat bu duruma karşıt bir düşünceyle Hıristiyan âlemi son peygamber Hz. Muhammed'i (s.a.v.) inkâr edip Tanrı́nın oğlu kabul ettikleri İsa Mesihi beklemektedirler. Yukarıda Nasrettin Hoca ile melek arasında geçen diyaloga cevap olarak Kur'an-1 Kerim'den şu ayetler; "Allah nezdinde hak din İslam'dır. Kitap verilenler, kendilerine ilim geldikten sonradır ki, aralarındaki kıskançlık yüzünden ayrilı̆̆a düştüler..." (Âl-i İmran 3/19) "Kim, İslam'dan başka bir din ararsa, bilsin ki kendisinden (böyle bir din) asla kabul edilmeyecek ve o, ahirette ziyan edenlerden olacaktır." (Âl-i İmran 3/85) gösterilebilir.

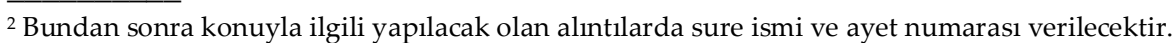


Son elçi Hz. Muhammed (s.a.v.) gelene kadar diğer bütün peygamberlerin onu müjdeleyici ve insanlığı uyarıcı olarak geldiği ve onlara inanarak Hz. Muhammed'in Allah'ın resulü olduğuna iman edenlere hiçbir korku olmadığg Kur'an'da bahsedilmektedir. Fakat bilindiği gibi Hıristiyanlık Antik Pagan kültürünün etkisi ve Ortaçağ'da kilisenin baskısıyla dönüştürülmüştür. İsa'nın Tanrı'nın oğlu olduğuna ve beklenilen Mesih olduğuna inanılmıştır. Modernizme gelindiğinde ise aydınlar, dinin insanların huzurunu kaçırdığına ve geleneklerden uzaklaşmak gerektiğine inanmışlardır. Buradan hareketle Adıvar'ın modernleşmenin etkisiyle inanç çatışması yaşadığını söyleyebiliriz.

Modernizm ile pek çok din ve kutsal metinler tahrip edilerek dönüştürülmeye çalışılmıştır. Bu durumun Halide Edip'in eserine de yansıdığını görmek mümkündür. Nasreddin Hoca ahirette Shakespeare ile sohbet ederken sürekli karısının sesini duyduğunu ve bu durumdan rahatsız olduğunu şöyle dile getirir:

"HOCA: Görmedi işittim. Her nasılsa son nefesimde bir hata ettim. Son dileğim bir değil, ikiydi. Biri Bozoğlan'la cennet adlı bostanda komşuluk, öteki karının yüzünü bir daha görmemek... biri tam, biri yarım kabul edilmiş! Karıyı görmüyorum, fakat arada sırada sesini işitiyorum... Ah bu ses olmasa, cennette ne yilan ne de Havva olacaktı." (s. 65-66)

Yazar, Nasreddin Hoca aracılığıyla Hz. Âdem ve Hz. Havva'nın cennetten çıkarılması olayına atıfta bulunmaktadır. Lakin İslam kültüründe Hz. Âdem ile Hz. Havva'nın cennetten çıkarılması olayında "yılan" unsuru anlatılmamakla birlikte olayda geçen yılanın sadece Yahudi kültüründe var olduğu bilinmektedir. Kur'an'da bu olaydan şöyle bahsedilmektedir:

"Biz: Ey Âdem! Sen ve eşin (Havva) beraberce cennete yerleşin orada kolaylikla istediğiniz zaman her yerde cennet nimetlerinden yeyin; sadece şu ă̆aca yaklaşmayın, eğer bu ă̆açtan yerseniz her ikiniz de kendine kötülük eden zalimlerden olursunuz, dedik.

Şeytan onlarm ayakların kaydırı haddi tecavüz ettirdi ve içinde bulundukları (cennetten) onlar çıkardı. Bunun üzerine: Bir kısmınız diğerine düşman olarak ininiz, sizin için yeryüzünde barınak ve belli bir zamana dek yaşamak vardır, dedik." (Bakara 2/35-36)

Bu hadise Kur'an'da farklı surelerde de geçmektedir. Diğer ayetlerde yasak bir ağacın meyvesini şeytanın hilesiyle yedikleri, edep yerlerinin kendilerine göründüğü ve örtmek içinde yaprak kullandıkları bahsedilmektedir. Bunun en belirgin örneği şöyledir:

“(Allah buyurdu ki): Ey Âdem! Sen ve eşin cennette yerleşip dilediğiniz yerden yeyin. Ancak şu ă̆aca yaklaşmayın! Sonra zalimlerden olursunuz.

Derken şeytan, birbirine kapalı ayıp yerlerini kendilerine göstermek için onlara vesvese verdi ve: Rabbiniz size bu ăgact sirf melek olursunuz veya ebedi kalanlardan olursunuz diye yasakladı, dedi.

Ve onlara: Ben gerçekten size öğ̈̈t verenlerdenim, diye yemin etti

Böylece onları hile ile aldattı. A ğacın meyvesini tattıklarında ayıp yerleri kendilerine göründü. Ve cennet yapraklarından üzerlerini örtmeye başladılar. Rableri onlara: Ben size o ăgacı yasaklamadım mi ve şeytan size apaçı bir düşmandır, demedim mi? diye nida etti. " (A'raf 7/1920-21-22) 
İslam kaynaklı metinlerde Hz. Havva ve Hz. Âdem'in cennetten çıkarılması olayında yılan unsuru bulunmadığı fakat farklı kaynaklarda değiştirilerek yazıldığı anlaşılmaktadır. Ayrıca eserde ahiret hayatındaki cennet -cehennem halkının kimlerden oluştuğu ve melek gibi varlıklar hakkında İslamiyet'le karşıt duran söylemler bulunmaktadır. Bu bağlamda tahrip edilen kutsal metinlerin dönüştürülmeye çalışıldığı ve bu evrilmenin arasında kalan aydın kesim ile halkın fikri bulanıklık yaşadığı söylenebilir.

\subsection{Metinlerarasılık}

Halide Edip eserinde birbirinden farklı pek çok metinlerarasıllı örneğine yer vermiştir. Gerek Doğu gerekse Batı medeniyetine özgü metinler, sanatçılar ve düşünürler eserde görülmektedir. Bunun en net örneğini Nasrettin Hoca'nın ahirette dolaşırken söylediği ilahide görmek mümkündür:

"Şol cennetin irmaklarl,

Akar Allah deyu deyu,

Cennette huri kızlarl,

Gezer Allah deyu deyu." (s. 58)

Yunus Emre'nin bu ilahisini söylemesi Türk-İslam kültürünün bir yansıması olarak dikkat çekmektedir. Nitekim Yunus Emre Anadolu'nun İslamlaşmasında etkin bir mutasavvıf olarak görülmektedir.

Adıvar İslamiyet'in ilk yıllarından itibaren öne çıkan bir isim olan sahabeden Bilal-i Habeşi'ye de yer vererek İslam'a bir atıfta bulunmaktadır. Ahirette sıkıntı içinde eşeğini arayan Nasrettin Hoca "siyah renkliler" temsilcisiyle sohbete başlar ve durumunu anlatır. Temsilci Nasrettin Hoca'ya yardım etmeye çalışır hatta ona bir ilahi okuyacağını ve bir şeyinin kalmayacağını söyleyerek ezan okumaya başlar. O vakit Nasrettin Hoca onun kim olduğunu anlar (s. 60-61).

Adıvar'ın biri asr-1 saadet döneminde İslam'ın kabulü ve yayılması için önemli rol oynayan sahabeden Bilal-i Habeş'e ve diğeri Anadolu'nun İslamlaşmasında gerek menkıbesi gerekse ilahileriyle değerli biri olan Yunus Emre'ye yer vermesinin geleneksel açıdan önemli olduğunu söyleyebiliriz.

Sadece İslam medeniyetine özgü değil diğer medeniyetlerden olan; Firavun, Dara gibi tarihte öne çıkmış şahsiyetlere de atıfta bulunur. Adıvar yalnız Doğu'nun sanatçılarına değil Batılı sanatçılara da yer vermiştir. Eserde Nasrettin Hoca ile W. Shakespeare'in ahirette arkadaş olduklarını ve şiirler söylediklerini görmek mümkündür. Halide Edip sadece bunlarla kalmaz dünya siyasetine ve felsefeye yön veren isimlerden de bahseder eserinde. Yazarın ABD başkanı Wilson'dan, Fransız siyasetçi Klemanso'ya ve Briyan'a kadar dünya siyasetinde tanınan isimlere ve İslam felsefecisi İbn-i Haldun'a kadar pek çok önemli isme eserinde yer verdiği görülür.

Eserde dünyadayken edindikleri bilgileri ahirettekilere iletmek için Nasrettin Hoca ve Shakespeare tekrar cennete döner. Bu arada Wilson, Klemanso, Briyan ve İbn-i Haldun'la karşılaşırlar. Ve aralarında dünya düzeniyle ilgili sohbet geçer. Aşağıda verilen diyalog bu durumun en belirgin örneğidir: 
"WILSON: Ben dünyaya, her derdine deva olacak on dört prensip bıraktım.

KLEMANSO: Fanilerin derdine Allah'ın on emri deva olmadı da senin on dört kuru lafin mı olacak?... Shakespeare, bizim kutsal devrimin üç prensibi dünyada yerleşmiş mi? Eşitlik, kardeşlik, özgürlük her yana yayılmış mı?

İBN-İ HALDUN: O esaslar Fransız inkılabının değil, İslamiyet'in.

BRIYAN: Onu birakın, asil sulh fikri ilerliyor mu, onu soralım...

SHAKESPEARE: Demokrasi dünya üstünden oklava geçmek, her şeyi bir örnek yapmak ise, o oluyor gibi... Esvaplar, üniforma gibi eş, suratlar maske gibi bir örnek..." (s. 106)

Bu bağlamda Adıvar metinlerarasılık yöntemiyle, birbirinden farklı iki ayrı medeniyetin temsilcilerini kullanarak modernizm ve gelenek arasında kalan bireyin karşıtlığını ve arada kalmışlı̆̆ını vermeye çalıştığına dair kanaat edinebiliriz.

\section{SONUÇ}

Avrupa'da 18. yy'da başlayan aydınlanma hareketi zamanla bütün dünyaya yayılmış ve geniş kitleleri etkisi altına almıştır. Modernizm akıl, bilim ve teknoloji sayesinde her sorunun üstesinden gelinebileceğini öngören bir düşünce tarzıdır. Bu düşünce tarzını benimseyenlere göre gelenek ile inanç insan yaşamını zorlayan ve sıkıntıya sokan yegâne unsurlardır. Aydınlara göre insanlar doğaya aklın ve bilimin ışı̆̆ıyla egemen olabilir. Dolayısıyla inanç ve gelenekten uzak bir düşünce tarzı benimsendiğini söyleyebiliriz. Modernizmin profan (din-dışılık) algısı karşısında kutsal değerler tamamen yıkılmamış fakat uyum sağlamak için evrilerek değişime uğramıştır. $\mathrm{Bu}$ düşünce tarzını benimsemeyenler ise gerici ya da çağdışı olarak adlandırılmıştır.

Rönesans hareketiyle başlayan, coğrafi keşifler ve sanayi inkılabıyla devam eden modernizm bu dönemde ivme kazanmıştır. Bununla beraber Batılı devletler sömürge yarışına girmiş ve sömürge ülkelerinde kendi politikalarını uygulamaya çalışmışlardır. Sömürge devletlerinin dini ve kültürel yapısını tahrip ederek yayılmacı bir politika izlenmeye gayret edilmiştir. Lakin sömürge devletleri buna karşı çıkmaya ve ayaklanmaya başlamışlardır.

Batılı devletlerin sömürü ve pazar yarışı ile Fransız Devrimi'nin getirdiği ulus-devlet anlayışı insanlığı iki büyük dünya harbinin eşiğine getirmiştir. Bunun neticesinde uzun yıllar süren hem insanlığa hem de doğaya derin izler bırakan savaşlar yaşanmıştır.

İnsanlık tarihinin en önemli dönüşümlerinden olan modernizm aydınların ve toplumların beklentisini karşılayamamıştır. Halk modernizmin başarışız olmasıyla kaosa sürüklenmiş ve ideal olanı bulma arayışına girmiştir. Bu arayış döneminde aydınlar ve halk buhrana girmiş ve çıkmazda kalmışlardır.

Devrin çıkmazları ve aydınların buhranı, gelenek ile modernizm arasındaki çelişkili durumları sanata ve edebiyata da yansımıştır. Bu süreç içerisinde aydınlar ideal nesil ve ideal dünya düzeni üzerinde çeşitli yollara başvurmuşlardır. İdeal olanın belirlenmesinde her sanatçı kendine göre bir yol izlemiştir.

Ülkemiz aydınları ise kimi köktenci bir tutumla ideali kendi kültür ve geleneğimizde ararken kimide Batılı gibi yaşamanın ve modern dünyanın getirilerini kavramanın ideal olacağını düşünmüştür. Bu arayış içerisinde Milli Mücadele dönemi aydınlarımızdan olan Halide Edip'te ideal neslin ve ideal dünya düzeninin nasıl olması gerektiğinden bahseden eserler vermiştir. Bu bağlamda 1945 yılında yayınlanan Maske ve Ruh tiyatrosu ideal olanı arayan bir aydının modernizm ve gelenek arasında kalan fikri çatışmasını göstermektedir. 
Halide Edip, Maske ve Ruh eserinde 21. yüzyıl Doğu toplumlarının yaşayabileceği muhtemel bir soruna yer vermiştir. Eserde insanların artık modern hayatın gereklerine uyarak robotlaştı̆̆ı, makineleşerek birer maske taktığı yansıtılır. Oyunun başkişilerinden Nasır (Nasrettin Hoca) insanlara unuttukları manevi kavramları, ruhun ve eskinin önemini hatırlatmak ister. Cennet, cehennem ve dünya arasında geçen fantastik bir oyundur. Eserdeki karakterlerin bir kısmı; modern, Batıll, makineleşmiş bir dünya ideali düşünürken diğer bir kısım duygusunu ve ruhunu kaybetmeyen, inançlarına ve geleneğine sahip çıkan bir dünya idealinin peşindedir. Ayrıca gerek Doğu ve gerekse Batı kültürünü yakından tanıyan Halide Edip, pek çok kültürü ve inancı birbirine sentezleyerek yazmıştır. Lakin bu kültürel birikimin bazı noktalarında özellikle dinler arasındaki bilgi ve kültür alışverişinde bazı çatışmalar, fikri bulanıklar görülmektedir. Yazarın bu çatışmalarına sebep olarak modernizmle gelen profan anlayış gösterilebilir.

Sonuç olarak 18. yüzyıldan günümüze değin modernizm ve geleneğin karşıtlı̆̆ına çözüm bulmaya çalışan aydınlar bu doğrultuda pek çok eser vermiştir. II. Meşrutiyet Dönemine gelindiğindeyse Doğu geleneğiyle yetiştirilmiş düşünürlerin modernizm sorunsalı göze çarpmaktadır. Bu dönemin önde gelen isimlerinden olan Halide Edip'in eserinde ideal insanı ve dünya düzenini arayan, modernizm ile gelenek arasında kalan aydının fikir çatışması görülmektedir. Maske ve Ruh, fikri olarak Batı'da, ruh ve duygusuyla Doğu'da, bedeni ile Araf'ta kalan bir aydının modernizm ve gelenek arasındaki çıkmazıdır denilebilir.

\section{SUMMARY}

Modernism is a way of thinking in which the reason and science are imposed instead of God and tradition, and which asserts that only world order established in this way can bring the welfare. It tries to destroy everything which belong to culture, belief, and tradition but cannot be explained by reason and science. Since belief and tradition shape the life and activities of the society out of its will, it leaves the reason and science aside. Since Modernism refuses everything in which the reason and science do not dominate, it tries to eliminate belief and tradition. It tries to use the art, philosophy and literature in order to achieve this. Modernists try to destroy the culture, which has become deep-rooted, however this situation takes time. The intellectuals stay on the horns of dilemma. The situation of the intellectuals and the society, who have a dilemma between the tradition and modernism in this regard, has also been reflected in the works of literature, as well. In this sense, in the play titled "Mask And Spirit" of Halide Edip, who is the one of the thinkers of the Second Constitutional Period, it was attempted to examine the intellectuals and the society which stay in conflict between tradition and modernism.

Halide Edip, one of the major figures of the period of War of Independence, known with her stories and novels, has works that she has written also by using theatrical form, as well. She has included the future and the transformation of the society as well as arguments to be possibly lived in the future by using this kind. In her play titled "Mask and Spirit", the history, cultural, political and religious problems of the society are discussed along with a mask and spirit relation.

In her work titled "Mask and Spirit", Halide Edip has included a possible problematic situation which the 21st century eastern societies may have. In the work, people who have become robotized, mechanized and put on a mask in accordance with the requirements of modern life are reflected. 
Nasir (Nasreddin Hodja) who is one of the protagonists in the play, wants to remind the people the spiritual concepts that they have forgot and the importance of the soul and the 'old'. This is a fantastic play taking place between Heaven, Hell and the World. Some of the characters in the play think about a modern, western, and mechanized World, on the other hand the other ones think about a dream for the World which has not lost its feelings and spirit and protects its beliefs and traditions. Halide Edip, who knows both eastern and western cultures closely, also has written her works by synthesizing many cultures and beliefs into each other. However, there are some conflicts, intellectual blurring at some points of this cultural accumulation, especially in information and culture exchange among religions. It is possible to show the profane understanding, which has come along with modernism, as the reason for these conflicts.

Consequently, the intellectuals, who have tried to find a solution to the contradiction of modernism and tradition from the 18th century until today, have composed many works in this direction. On the other hand, at the time of the Second Constitutional Period, the modernism problematic of the thinkers raised with eastern tradition draws the attention. In the work of Halide Edip, who is one of the major figures of this period, there is a clash of ideas of the intellectuals who were for the ideal human and world order and who stayed between the modernism and the tradition. It is possible to say that the "Mask and Spirit" is a dilemma of an intellectual between the modernism and tradition. 


\section{KAYNAKÇA}

ADIVAR, Halide Edip (1968). Maske ve Ruh. Ankara: Atlas Kitabevi.

AKALIN, Şükrü Halûk-TOPARLI Recep vd. (2011). Türkçe Sözlük. Ankara: TDK Yay.

AKTAY, Yasin (2008). "Kavramsal Açıdan Modernizm ve Postmodernizm'e Bakmak". Hece Dergisi (138/139/140): 8-10.

GÜNEŞ, Eyüp (2014). Rasim Özdenören'in Hikâyelerinde Gelenek-Modernizm Çatışması. Yüksek Lisans Tezi. Adıyaman: Adıyaman Üniversitesi.

HARVEY, David (1997). Postmodernliğin Durumu. çev. Sungur Savran. İstanbul: Metis Yay.

KIZILÇELIKK, Sezgin (1994). Postmodernizm Dedikleri. İzmir: Saray Kitabevi.

KOÇAKOĞLU, Bedia (2012). Anlamsızlı̆̆ın Anlamı Postmodernizm. Ankara: Hece Yay.

ÖZEK, Ali-KARAMAN, Hayreddin vd. (2012). Kur'ân-ı Kerim Açıklamalı Meâli. Ankara: TDV Yay.

YILDIZ, Ecevit (2001). Türk Romanında Postmodernist Açılımlar. İstanbul: İletişim Yay. 